University of Montana

ScholarWorks at University of Montana

4-29-2015

\title{
Reproductive performance of Kittlitz's Murrelet in a glaciated landscape, Icy Bay, Alaska, USA
}

Michelle L. Kissling

U.S. Fish and Wildlife Service

Scott M. Gende

National Park Service

Stephen B. Lewis

U.S. Fish and Wildlife Service

Paul Lukacs

University of Montana - Missoula, paul.lukacs@umontana.edu

Follow this and additional works at: https://scholarworks.umt.edu/wildbio_pubs

Part of the Biodiversity Commons, and the Biology Commons

Let us know how access to this document benefits you.

\section{Recommended Citation}

Kissling, Michelle L.; Gende, Scott M.; Lewis, Stephen B.; and Lukacs, Paul, "Reproductive performance of Kittlitz's Murrelet in a glaciated landscape, Icy Bay, Alaska, USA" (2015). Wildlife Biology Faculty

Publications. 86.

https://scholarworks.umt.edu/wildbio_pubs/86

This Article is brought to you for free and open access by the Wildlife Biology at ScholarWorks at University of Montana. It has been accepted for inclusion in Wildlife Biology Faculty Publications by an authorized administrator of ScholarWorks at University of Montana. For more information, please contact scholarworks@mso.umt.edu. 


\title{
Reproductive performance of Kittlitz's Murrelet in a glaciated landscape, Icy Bay, Alaska, USA
}

\author{
Michelle L. Kissling, ${ }^{1 *}$ Scott M. Gende, ${ }^{2}$ Stephen B. Lewis, ${ }^{1}$ and Paul M. Lukacs ${ }^{3}$ \\ ${ }^{1}$ U.S. Fish and Wildlife Service, Juneau, Alaska, USA \\ ${ }^{2}$ National Park Service, Juneau, Alaska, USA \\ ${ }^{3}$ Wildlife Biology Program, Department of Ecosystem and Conservation Sciences, University of Montana, Missoula, Montana, USA \\ * Corresponding author: michelle_kissling@fws.gov
}

Submitted April 18, 2014; Accepted February 18, 2015; Published April 29, 2015

\begin{abstract}
Kittlitz's Murrelet (Brachyramphus brevirostris) is a dispersed-nesting seabird endemic to Alaska and eastern Russia that may have experienced considerable population declines in some parts of its range in the past few decades. Poor reproduction has been suggested as the demographic bottleneck, yet there are no direct estimates of reproduction in a glaciated area where this species reaches its highest densities at sea during the breeding season. The lack of demographic information in glacial habitats has limited our ability to interpret population trends and to clarify whether the presence of glaciers affects reproductive performance. Between 2007 and 2012, we radio-tagged Kittlitz's Murrelets to measure breeding propensity, nesting success, and fecundity in the heavily glaciated landscape of Icy Bay, Alaska, USA. Of 156 radio-tagged birds, $20 \%$ were breeders, $68 \%$ were potential breeders, and $12 \%$ were nonbreeders. Radio-tagged males (29\%) were more likely to be breeders compared to females (11\%). Across all years, we located 34 Kittlitz's Murrelet nests, 38\% of which were successful. Daily nest survival probability ( \pm SE) was $0.979 \pm 0.005$, with most nests failing during incubation; if extrapolated to a 55-day period from nest initiation to fledging, the nest survival rate was $0.307 \pm 0.083$. Low fecundity was due largely to low breeding propensity, not low nesting success. For context, we also determined the breeding status of 14 radio-tagged Marbled Murrelets (B. marmoratus), most of which were breeders (79\%) and successfully fledged young (69\%). Our data demonstrated that Kittlitz's Murrelets were outperformed in all facets of reproduction compared to Marbled Murrelets. Low fecundity estimates for Kittlitz's Murrelet were consistent with a 10\% per annum decline in Icy Bay between 2002 and 2012, suggesting that poor reproductive performance contributed to the local population decline of this species.
\end{abstract}

Keywords: Brachyramphus, breeding propensity, glacier, Kittlitz's Murrelet, nesting success, population decline, reproduction

\section{Desempeño reproductivo de Brachyramphus brevirostris en un paisaje glacial, Icy Bay, Alaska \\ RESUMEN}

Brachyramphus brevirostris es un ave marina de anidación dispersa, endémica de Alaska y el oriente de Rusia, que podría haber experimentado declives poblacionales considerables en algunas partes de su distribución durante las décadas pasadas. Se ha sugerido que la baja reproducción causa un cuello de botella poblacional, aunque no hay estimados directos de la reproducción en el área glacial donde esta especie presenta mayores densidades en el mar durante la temporada reproductiva. La falta de información demográfica en los hábitats glaciales ha limitado nuestra habilidad para interpretar tendencias poblacionales y aclarar si la presencia de los glaciares afecta el desempeño reproductivo. Entre 2007 y 2012 marcamos individuos de B. brevirostris con radiotransmisores para medir la tendencia a reproducirse, el éxito de anidación y la fecundidad en un paisaje altamente glacial, lcy Bay, Alaska. De 156 aves marcadas, $20 \%$ se reprodujeron, $68 \%$ eran potencialmente reproductivos y $12 \%$ no se reprodujeron. Los machos marcados (29\%) tuvieron mayor probabilidad de reproducirse que las hembras (11\%). En todos los años localizamos 34 nidos de $B$. brevirostris, de los cuales el $38 \%$ fueron exitosos. La probabilidad de supervivencia diaria de los nidos ( $\pm \mathrm{EE}$ ) fue 0.979 ( \pm 0.005$)$ y la mayoría de los nidos fracasaron durante la incubación; si se extrapola al periodo de 55 días desde el inicio de los nidos hasta el emplumamiento, la tasa de supervivencia de los nidos fue 0.307 ( \pm 0.083 ). La baja fecundidad se debió en gran parte a la baja propensión a reproducirse y no al bajo éxito de anidación. A manera de contexto también determinamos el estado reproductivo de 14 individuos de la especie $B$. marmoratus marcados con transmisores de radio, la mayoría de los cuales se reprodujeron (79\%) y sus polluelos emplumaron exitosamente (69\%). Nuestros datos demuestran que $B$. brevirostris fue superado en todas las facetas reproductivas por B. marmoratus. Los bajos estimados de fecundidad para B. brevirostris fueron consistentes con un declive poblacional anual del $10 \%$ en Icy Bay entre 2002 y 2012, lo que sugiere que el bajo desempeño reproductivo contribuyó al declive local de esta especie. 
Palabras clave: Brachyramphus, declive poblacional, éxito de anidación, glaciar, propensión a la reproducción, reproducción

\section{INTRODUCTION}

Kittlitz's Murrelet (Brachyramphus brevirostris) is a small seabird endemic to Alaska and the Russian Far East. This species may have experienced considerable population declines in some parts of its range within the past few decades (Kuletz et al. 2011a, 2011b, Piatt et al. 2011), although the reliability of some surveys has been debated (Day 2011, Hodges and Kirchhoff 2012, Kuletz et al. 2013, Kirchhoff et al. 2014). During the breeding season, a large fraction of the global population occupies marine waters near tidewater glaciers, remnant high-elevation glaciers, and outflows of glacial-fed rivers (U.S. Fish and Wildlife Service [USFWS] 2013). This habitat association and the rapid wastage of tidewater glaciers in Alaska have been implicated as a possible causal factor for population changes (e.g., Kuletz et al. 2003), but a mechanistic link connecting demographic changes with habitat attributes has not been identified. Contributing to the uncertainty in their current status, populations appear to have stabilized in recent years (Kuletz et al. 2011a, Piatt et al. 2011, USFWS 2013). Kittlitz's Murrelet was registered as a candidate for listing under the U.S. Endangered Species Act in 2004 but, ultimately, was not listed as threatened or endangered, largely owing to the lack of an identified population- or species-level threat (USFWS 2013).

Unlike most other seabird species, Kittlitz's Murrelets do not nest in colonies but instead nest in low densities on the ground or on cliff ledges, usually in remote, mountainous areas that are unvegetated or sparsely vegetated. Breeding females lay $1 \mathrm{egg}$, and parents alternate incubation for $\sim 30$ days. If hatching follows, both parents feed the chick single whole fish at the nest until fledging, typically 20-30 days later (Day et al. 1999, Kaler et al. 2009, Lawonn 2012). Kittlitz's Murrelet has cryptic plumage and secretive nesting behaviors, especially during chick rearing, when the chick is left largely unattended, presumably to minimize detection by predators. Given its purposefully obscure breeding habits, it is not surprising that only 17 nest records existed as of 1999.

Recently, targeted research efforts have resulted in the discovery of nearly 200 Kittlitz's Murrelet nests using ground searches by foot in accessible, unglaciated areas of Alaska, including Kodiak Island (Lawonn 2012; Figure 1), the Aleutian Archipelago (Kaler et al. 2009; Figure 1), and the Kakagrak Hills of northwestern Alaska (M. L. Kissling and S. B. Lewis personal observation). These studies suggest that nesting success of Kittlitz's Murrelets is low (combined across years: $19-23 \%$ study site ${ }^{-1}$; summarized in USFWS 2013) and thus support the assertion that poor reproduction may limit population growth in this species (Day and Nigro 2004, Kaler et al. 2009). Nevertheless, inferences from these studies are limited to habitat accessible by foot, which excludes the mountainous, recently glaciated landscapes presumably preferred by Kittlitz's Murrelets, as evidenced by their comparatively high densities at sea in glacially affected marine waters (e.g., Kissling et al. 2011). Furthermore, information from active nests does not reveal breeding propensity (i.e. the probability that a mature adult will attempt to breed in a given year), a critical demographic attribute when considering reproductive performance and population dynamics in birds (Cam et al. 1998, Bond et al. 2008).

We studied the reproductive performance of Kittlitz's Murrelets in a glaciated landscape over a 6-yr period, 2007-2012. Specifically, we estimated annual breeding propensity, nesting success, and fecundity by capturing and radio-tagging birds in the spring and relocating them throughout the breeding season. For context, we used identical methods to study, to a much lesser extent, the reproductive performance of the Marbled Murrelet ( $B$. marmoratus), a closely related species that has similar foraging habits and is therefore subject to the same environmental conditions.

\section{METHODS}

\section{Study Area}

Our study was centered in Icy Bay, Alaska, USA, located in the northeastern Gulf of Alaska, $\sim 110 \mathrm{~km}$ northwest of the town of Yakutat (Figure 1). Icy Bay is a highly dynamic glacial fjord system that has experienced multiple, rapid ice advances and retreats over the past 4,000 yr; the most recent retreat of $\sim 40 \mathrm{~km}$ occurred during the 20th century (Barclay et al. 2006). Currently, Icy Bay comprises a shallow outer bay and a deeper inner bay. The outer bay, 6 $\mathrm{km}$ wide at its mouth, is adjacent to the Gulf of Alaska, and the inner bay is divided into 4 distinct fjords, each terminating at an active tidewater glacier. The total surface area of Icy Bay is $\sim 263 \mathrm{~km}^{2}$, but typically the upper half of the bay is covered in thick ice floes and large icebergs. The uplands adjacent to the inner bay are dominated by the high peaks of the St. Elias and Robinson mountains, most of which are 1,000-2,000 $\mathrm{m}$ in elevation, although Mt. St. Elias, $20 \mathrm{~km}$ from tidewater, reaches $5,489 \mathrm{~m}$. Permanent snow and ice of the 4 tidewater glaciers, the Malaspina Glacier, and other glaciers extend from the Bagley Icefield ( $\sim 30 \mathrm{~km}$ from tidewater). 


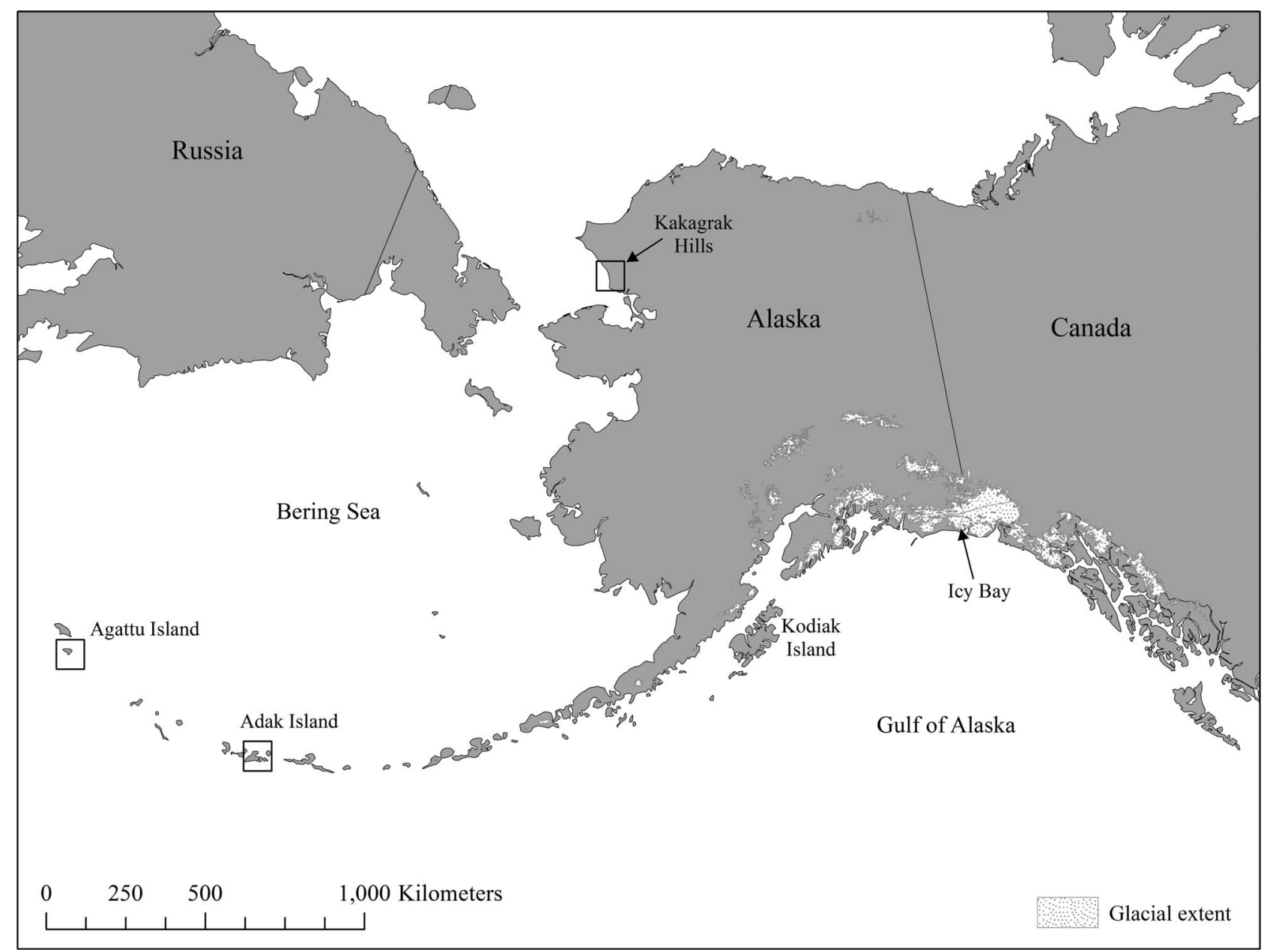

FIGURE 1. Location of Icy Bay, Alaska, USA, where we conducted our study on the reproductive performance of Kittlitz's Murrelets, 2007-2012. Locations of other Kittlitz's Murrelet nesting-ecology studies (see text) are also shown: Kodiak, Agattu, and Adak islands in the Aleutian Archipelago, and Kakagrak Hills in northwestern Alaska.

\section{Field Methods}

Capture, radio-tagging, and radio-tracking. We captured Kittlitz's and Marbled murrelets on the water using the night-lighting method (Whitworth et al. 1997) in and near Icy Bay between May 8 and June 3 each year for $6 \mathrm{yr}$, 2007-2012. This period generally corresponded to the arrival of Kittlitz's Murrelets in the nearshore waters of Icy Bay prior to nesting (Day 1996). For each bird captured, we recorded the capture location, time, group size, and number of capture attempts. If, after 3 attempts, an individual could not be netted, we abandoned the effort in order to minimize disturbance to the bird. If 1 bird of a pair was captured, we attempted to capture the second bird. We placed each captured bird into a mesh bag (Sea to Summit, Boulder, Colorado, USA) that was placed into a water-resistant cardboard pet carrier lined with a towel; if both birds of a pair were captured, they often were placed in the same carrier but in different mesh bags.
Following capture, we transported birds to a larger vessel where we processed them individually, generally in the order of arrival at the processing vessel. We weighed each bird, measured natural wing chord and tail length, and attached a uniquely numbered band to the right leg. We noted overall plumage characteristics, including body or wing molt, and any deformities and injuries, and examined the underwing plumage to distinguish secondyear (SY) birds from after-second-year (ASY) birds (Pyle 2008). Brood patches develop in both sexes; we scored brood patch (BP) development following Sealy (1974; BP $0-6)$. We drew $<2$ cc of blood from the ulnar vein for sex determination (Zoogen, Davis, California, USA).

Each year, we deployed VHF radio-transmitters on a subset of captured ASY individuals (range: 24-44 individuals $\mathrm{yr}^{-1}$ ) for a total of 191 individuals ( 95 females and 96 males) across the 6-yr period of our study. When sea conditions allowed us to attach transmitters, we chose 
individuals to radio-tag at random, provided that they did not have any obvious injuries, deformities, or other physical limitations. We attached the transmitters (Advanced Telemetry Systems, Isanti, Minnesota, USA [ATS]; model no. A4360, $<3.2 \mathrm{~g}$ in weight, $\sim 1.5 \%$ of bird's mass) using a subcutaneous anchor on the bird's back between the scapulars, following Newman et al. (1999) but with a few deviations. In 2007 and 2008, we did not use a local anesthetic at the attachment site and we glued the posterior part of the transmitter to the back feathers of the bird with a cyanoacrylate adhesive (3M VetBond Tissue Adhesive; Lougheed et al. 2002). In 2009-2012, we infused $2 \mathrm{mg} \mathrm{kg}^{-1}$ of a local anesthetic (1\% solution of Lidocaine) under the skin on the back of the neck where the transmitter was to be attached, and we secured the posterior part of the transmitter to the bird with one 3-0 monofilament, nonabsorbable suture. Birds were immediately released from the processing vessel. If both birds of a pair were captured, we randomly selected 1 bird to radiotag, to ensure independence and to minimize disturbance to nesting pairs, and we released the pair together.

In the earlier years of the study (2007-2009), we focused capture efforts on Kittlitz's Murrelets but occasionally captured Marbled Murrelets accidentally, owing to their similarities in plumage, size, and overlap in distribution. Usually these individuals were released immediately after capture. However, beginning in 2010, we aimed to capture a small number of Marbled Murrelets to provide context to our study of Kittlitz's Murrelets, and in 2011 and 2012, we radio-tagged 16 of them (6 females and 10 males).

Nest location and monitoring. We attempted to locate radio-tagged birds 2-5 times $\mathrm{wk}^{-1}$ (mean $=3.5 ; \mathrm{SD}=1.5$ ) for $\geq 8$ wk using fixed-wing aircraft equipped with $\mathrm{H}$-style antennas mounted on the struts. Generally, we began flying to locate radio-tagged birds immediately after capture. We first attempted to locate all radio-tagged individuals on the water in or near Icy Bay; if birds were not detected at sea, we flew over all assumed potential nesting habitat, within reason (e.g., fuel constraints), to locate incubating birds. We attempted to access by foot all locations where signals were found on land, to determine whether the bird was incubating or dead or whether the transmitter had become detached. Given the mountainous terrain, remote location, and often inclement weather of our study site, we were not able to locate radio-tagged birds daily using aerial or ground telemetry, as has been done in other murrelet telemetry studies (Bradley et al. 2004, Peery et al. 2004b). We adjusted flights to maximize the opportunities to locate incubating radio-tagged birds that typically switch incubation at intervals of 24-48 hr (Lawonn 2012).

If a nest was located from the air and it was deemed accessible on foot, we immediately searched for the incubating radio-tagged bird using handheld receivers and antennas. As soon as possible thereafter, we deployed a remote video camera system with an infrared camera for night recording (SeeMore Wildlife Systems, Homer, Alaska, USA, or similar). The camera was placed $2-3 \mathrm{~m}$ from the nest, which required flushing the incubating adult once during setup; the recording equipment was located out of sight of the nest (usually $>50 \mathrm{~m}$ connected via coaxial cable) to allow for battery changes and downloading of video without disturbing the nest (Figure 2A). However, the majority (91\%) of nests were not accessible by foot, even with the assistance of fixed-wing aircraft and helicopter. Therefore, we monitored nearly all nests remotely using data loggers (ATS, model R4500S; and Telonics [Mesa, Arizona, USA], model TR-5) with 4element antennas set up within $5 \mathrm{~km}$ of the nest (Figure $2 B)$. The data loggers were programmed to scan for the frequency of the nesting bird once every $10 \mathrm{~min}$ for $30 \mathrm{~s}$. We determined these scan parameters on the basis of the pulse rate $(55 \mathrm{ppm})$ and width $(18 \mathrm{~ms})$ of the transmitter signal, battery power usage, and nesting behavior. During incubation, we expected the egg to be attended continually by one of the parents; and during chick rearing, adult Kittlitz's Murrelets often remain at the nest for 10-15 min, typically before transferring the fish to the chick (Lawonn 2012, M. Kissling personal observation). We downloaded the data loggers and swapped batteries as often as possible; in some cases, we could not revisit the system until after the nesting period.

\section{Data Analyses}

Breeding propensity. Following Peery et al. (2004b), we classified radio-tagged birds into 3 categories based on their apparent reproductive status: (1) "breeder," defined as a bird that was observed or inferred to be nesting; (2) "potential breeder," a bird in breeding condition at the time of capture that ultimately did not initiate nesting; or "nonbreeder," a bird that was not in breeding condition at the time of capture and did not initiate nesting. For clarity, we refer to birds that did not nest (as determined by radiotelemetry) as "non-nesting" regardless of their breeding condition (i.e. potential breeders and nonbreeders combined). We classified a bird as "non-nesting" if it was never relocated in the uplands but was located on the water during $\geq 50 \%$ of the flights completed from the time of capture to June 23 , when $90 \%$ of the breeders initiated nesting (following Peery et al. 2004b). If a bird did not initiate nesting and either died or was not located regularly on the water (defined as located on $<50 \%$ of the flights completed), presumably because it permanently left the study area or the radio-tag failed or detached from the bird by June 23, we removed it from further analysis (Peery et al. 2004b). Across all years, we removed 35 Kittlitz's Murrelets because we did not locate them frequently enough to determine reproductive status $(n=25)$ or 


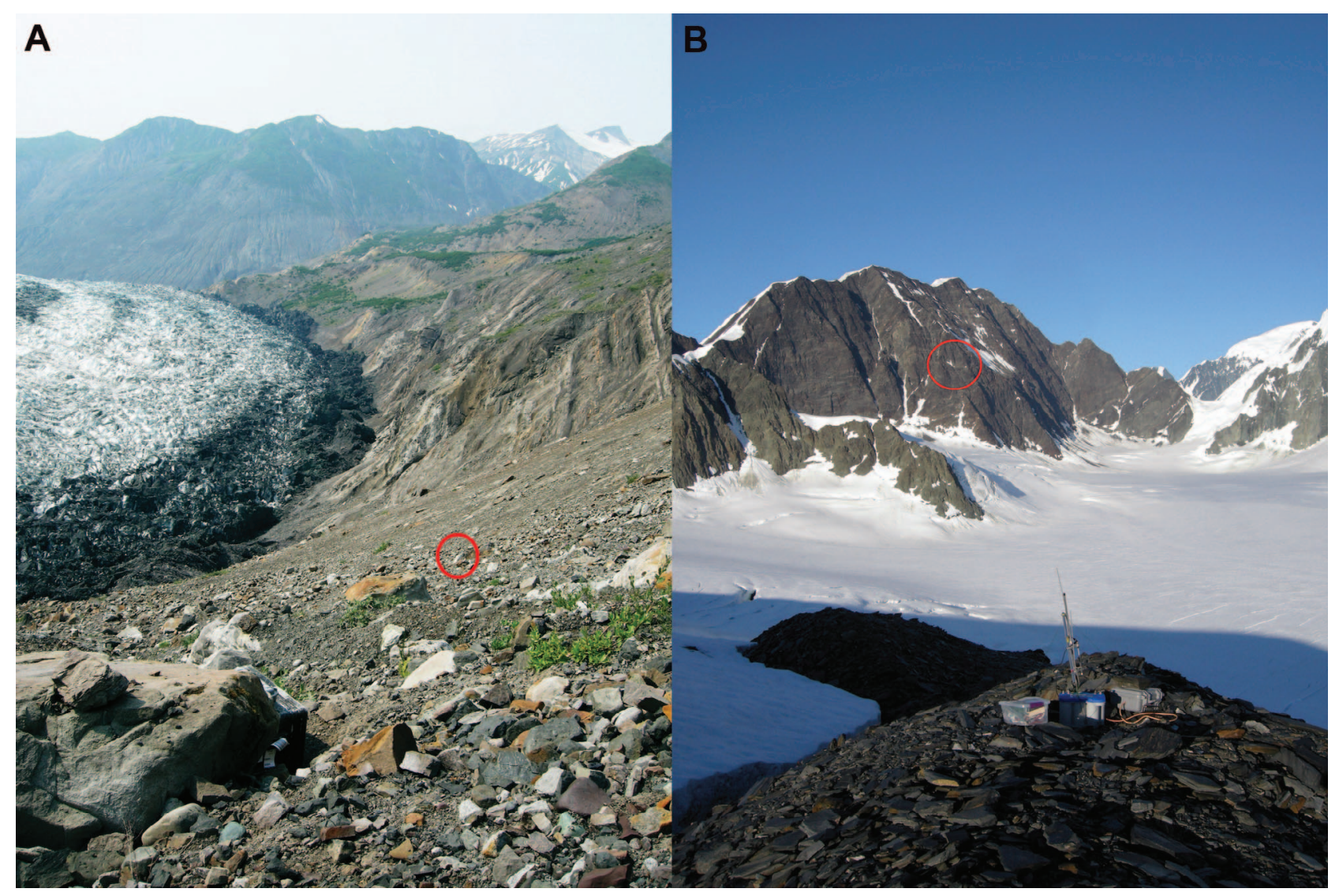

FIGURE 2. Examples of nests at Icy Bay, Alaska, USA, 2007-2012: (A) A helicopter-accessible Kittlitz's Murrelet nest, with remote camera system in foreground; and (B) an inaccessible nest, with remote data-logger setup directed at the nest site. Nest locations are circled in red.

fatality $(n=10)$ and 2 Marbled Murrelets because of an insufficient number of locations prior to June 23.

Breeding propensity typically is defined as the probability that a sexually mature adult will nest in a given year. Age of first breeding of Kittlitz's Murrelet is assumed to be $\sim 3$ yr of age (Day et al. 1999). However, we are not aware of a field or laboratory method to distinguish an ASY Kittlitz's Murrelet that has not yet reached sexual maturity (i.e. subadult) from a sexually mature adult. Thus, we defined "breeding propensity" as the probability that an ASY Kittlitz's Murrelet will breed, and measured it as the proportion of ASY individuals that were categorized as "breeders" in a given year. We used radio-telemetry as a direct measure of breeding activity to distinguish breeders from non-nesting birds and to estimate breeding propensity. We considered an individual a breeder if it was detected inland at least once during the breeding season and then was located on the water within $72 \mathrm{hr}$ of the inland location (i.e. the bird was not dead). We made 3 key assumptions: (1) Capture, handling, and radio-tagging did not affect initiation of breeding; (2) birds detected inland were attempting to nest (i.e. were not prospecting for nest sites or engaging in social behavior); and (3) individuals attempting to nest were detected inland at least once (i.e. failed nests were located).

We used the presence of a brood patch on males and females as an indirect measure of breeding condition to distinguish potential breeders from nonbreeders. We classified individuals of both sexes that had a brood patch (i.e. BP $=1-5$; Sealy 1974) at the time of capture as "potential breeders" and those without a brood patch (i.e. $\mathrm{BP}=0,6)$ as "nonbreeders" (McFarlane Tranquilla et al. 2003a, Peery et al. 2004b).

In 2007 and 2008 only, we also assessed plasma vitellogenin (VTG) of females captured during the spring session. Vitellogenin is an egg-yolk protein that becomes elevated in the plasma of female birds during egg production and has been used successfully as an indicator of breeding status in Marbled Murrelets (Vanderkist et al. 2000, Lougheed et al. 2002, McFarlane Tranquilla et al. 2003a, 2003b, Peery et al. 2004b, Janssen et al. 2009). We measured levels of vitellogenic zinc as an index to plasma VTG and used the threshold validated for Marbled Murrelet $\left(0.96 \mu \mathrm{g} \mathrm{mL}^{-1}\right)$ to distinguish potential breeders 
from nonbreeders (Vanderkist et al. 2000, McFarlane Tranquilla et al. 2003b).

Nesting success. We defined "nesting success" as the proportion of nests that survived both the incubation and fledging stages. Because Kittlitz's Murrelets lay a single egg, the proportion of successful nests is equivalent to the proportion of chicks fledged. We also modeled daily nest survival in Program MARK version 4.3 (Dinsmore et al. 2002) and extrapolated this probability to a 55-day period (30-day incubation period and 25-day chick-rearing period) to allow comparison with other nesting-ecology studies of Kittlitz's Murrelet (Kaler et al. 2009, Lawonn 2012). Given the small number of nests found annually in our study, we combined nests across years and assumed a constant daily survival rate with no covariates.

If we were unable to monitor a nest directly with a video camera, we had to infer the success of each nest stage using a combination of radio-telemetry and datalogger information. For those nests, we defined "successful incubation" as a nest that survived from egg laying to egg hatching, as determined by (1) $\geq 2$ independent (i.e. not on consecutive days) locations of the radio-tagged bird at the nest; (2) an incubation shift, either on or off the nest, of $\leq 72 \mathrm{hr}$; and (3) $\leq 30$ days of "on-nest/offnest" behavior of the radio-tagged individual. We did not find any nests prior to the start of incubation (to the best of our knowledge), so we back-calculated 30 days from the estimated hatching date to determine the nest initiation date. Following hatching, the chick is brooded continuously for $\geq 24 \mathrm{hr}$ (Lawonn 2012), which we included in our back calculations of estimated nest initiation date (i.e. 31-day period). During the remainder of the chick-rearing period, parents visit the nest only to deliver food (Kaler et al. 2009, Lawonn 2012), so we relied solely on data-logger information to determine success at the fledging stage. We assumed that nests were active if radio-tagged adults returned at least once every $48 \mathrm{hr}$ throughout the monitoring period (Bradley et al. 2004). We considered a nest to have reached the fledging stage successfully if it was active for $\geq 18$ days after hatching; we assumed this to be the minimum number of days of chick rearing because $90 \%$ of Kittlitz's Murrelet nests that were monitored directly but failed to fledge young did so within 18 days of hatching (R. Kaler personal communication; J. Lawonn personal communication; present study). We did not develop these definitions a priori, but instead used the video data collected at accessible nest sites, and our accumulated experience gained throughout the study, to define criteria for each nest stage prior to analysis.

Fecundity. We assessed annual reproductive performance of birds by estimating "fecundity," defined as the annual production of females per ASY female in the population. We estimated fecundity by calculating the product of breeding propensity, nesting success, and the sex ratio of female young (0.5, assuming an even sex ratio) in a given year. We chose this definition of fecundity to allow for inclusion in integrated population models (Schaub and Abadi 2011) and population viability analysis (Mills 2012) and for comparison with other nesting ecology studies of Brachyramphus (Bradley et al. 2004, Peery et al. 2004b). Results are presented as means \pm SE.

\section{RESULTS}

\section{Breeding Propensity}

During the $6 \mathrm{yr}$ of the study, we determined the reproductive status of 156 radio-tagged Kittlitz's Murrelets; 32 of them nested (breeders), 106 of them did not nest but were in breeding condition at the time of capture (potential breeders), and 18 did not nest and were not in breeding condition (nonbreeders). The mean annual proportion of radio-tagged Kittlitz's Murrelets by reproductive status was $0.20( \pm 0.07)$ breeders, $0.68( \pm 0.09)$ potential breeders, and $0.12( \pm 0.06)$ nonbreeders. Proportions varied among years $\left(\chi_{10}^{2}=26.933, P=0.003\right.$; Table 1 ) and by sex, with males more likely to be breeders than females $\left(\chi_{2}^{2}=9.229, P=0.01\right.$; Figure 3$)$. The differences in proportions of male and female breeders were most pronounced in 2011 and 2012 (Figure 3), when breeding propensity was higher overall (Table 1). Generally, in years of lower breeding propensity (2008-2010), the proportions of radio-tagged males and females by reproductive status were similar (Figure 3).

At the time of capture, the majority $(87 \% ; 136$ of 156$)$ of radio-tagged Kittlitz's Murrelets were in breeding condition, as determined by either presence of brood patch (81\%; 127 of 156) or elevated VTG in females $(87 \%$; 19 of $22)$. Most of the breeders (56\%; 18 of 32 ) had a fully developed brood patch $(\mathrm{BP}=3)$ at the time of capture; only a small percentage of breeders $(9 \% ; 3$ of 32$)$ did not have a brood patch. Only 2 of 15 radio-tagged females with elevated VTG in 2007 nested, and 0 of 4 in 2008 nested; both of these females had low brood patch scores $(\mathrm{BP}=0$ 1 ), indicating absence or beginning stages of a brood patch. Generally, females with elevated VTG (i.e. egg producers) did not have brood patches $(\mathrm{BP}=0)$ or were developing brood patches $(\mathrm{BP}=1-2)$, and females with full developed, vascularized brood patches $(\mathrm{BP}=3)$ had VTG levels below the threshold $\left(0.96 \mu \mathrm{g} \mathrm{mL}^{-1}\right)$.

In 2011 and 2012, Marbled Murrelets were more likely than Kittlitz's Murrelets to be breeders $\left(\chi_{2}^{2}=10.653, P=\right.$ 0.005; Figure 3). Combining both years, 11 radio-tagged Marbled Murrelets were breeders, 1 was a potential breeder, and 2 were nonbreeders (Table 1). All radiotagged male Marbled Murrelets (100\%; 9 of 9) were breeders, whereas only $40 \%$ ( 2 of 5 ) of radio-tagged females were breeders. 
TABLE 1. Annual proportions (with SE) of radio-tagged Kittlitz's and Marbled murrelets at Icy Bay, Alaska, USA, 2007-2012, by reproductive status. We defined a "breeder" as a bird that was observed or inferred to be nesting; a "potential breeder" as a bird in breeding condition (i.e. with a brood patch) at the time of capture that did not initiate nesting; and a "nonbreeder" as a bird that was not in breeding condition at the time of capture and did not initiate nesting ( $n=$ sample size).

\begin{tabular}{|c|c|c|c|c|c|c|c|}
\hline \multirow[b]{2}{*}{ Year } & \multicolumn{7}{|c|}{ Reproductive status } \\
\hline & $n$ & Breeder & SE & Potential breeder & SE & Nonbreeder & SE \\
\hline \multicolumn{8}{|c|}{ Kittlitz's Murrelet } \\
\hline 2007 & 27 & 0.15 & 0.07 & 0.63 & 0.09 & 0.21 & 0.08 \\
\hline 2008 & 20 & 0.05 & 0.05 & 0.75 & 0.10 & 0.20 & 0.09 \\
\hline 2009 & 24 & 0.08 & 0.06 & 0.79 & 0.08 & 0.13 & 0.07 \\
\hline 2010 & 34 & 0.12 & 0.06 & 0.79 & 0.07 & 0.09 & 0.05 \\
\hline 2011 & 29 & 0.45 & 0.09 & 0.48 & 0.09 & 0.07 & 0.05 \\
\hline 2012 & 22 & 0.36 & 0.10 & 0.64 & 0.10 & 0.00 & 0.00 \\
\hline Mean & & 0.20 & 0.07 & 0.68 & 0.09 & 0.12 & 0.06 \\
\hline Total $n$ & 156 & 32 & & 106 & & 18 & \\
\hline \multicolumn{8}{|c|}{ Marbled Murrelet } \\
\hline 2011 & 6 & 1.00 & 0.00 & 0.00 & 0.00 & 0.00 & 0.00 \\
\hline 2012 & 8 & 0.63 & 0.17 & 0.13 & 0.12 & 0.25 & 0.15 \\
\hline Mean & & 0.81 & 0.13 & 0.06 & 0.09 & 0.13 & 0.12 \\
\hline Total $n$ & 14 & 11 & & 1 & & 2 & \\
\hline
\end{tabular}

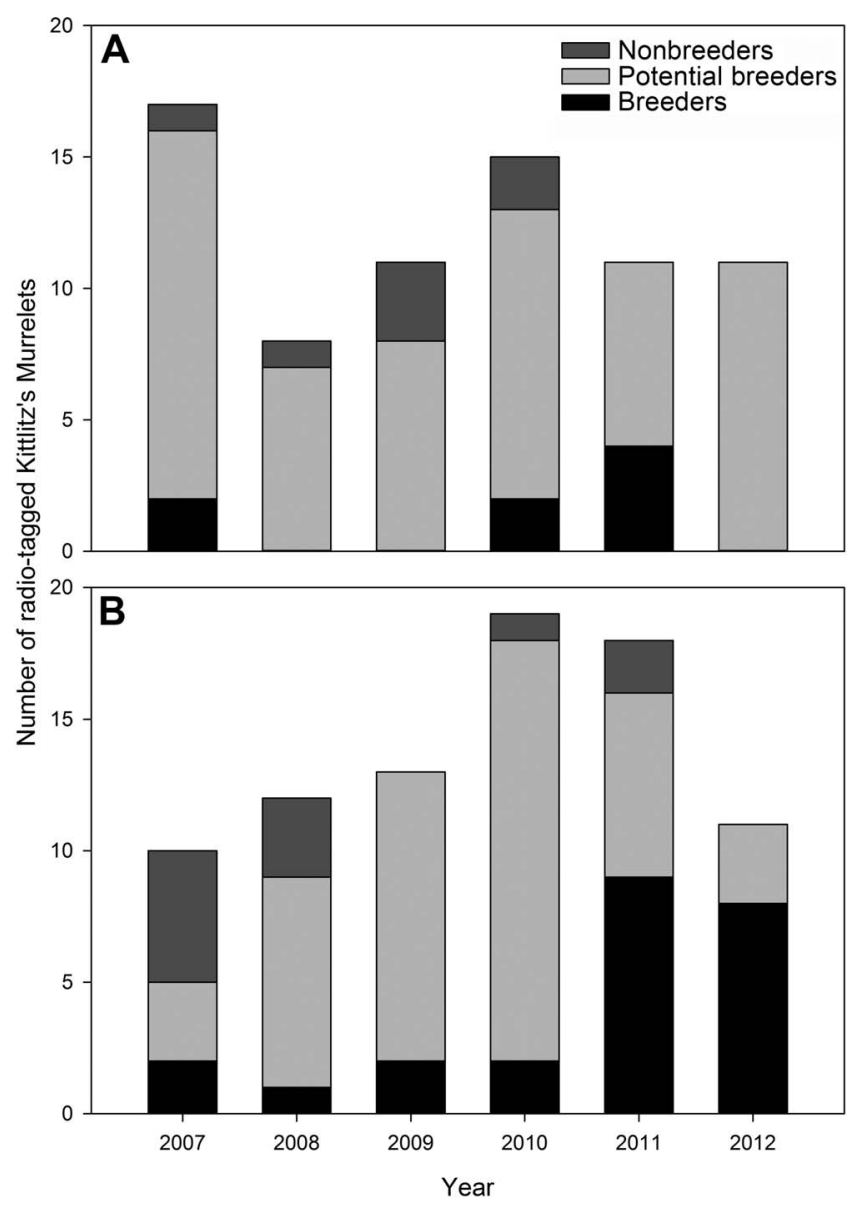

FIGURE 3. Annual proportions and sample sizes of (A) female and (B) male radio-tagged Kittlitz's Murrelets at Icy Bay, Alaska, USA, 2007-2012, by reproductive status.

\section{Nesting Success}

We located 34 nests of radio-tagged Kittlitz's Murrelets between 2007 and 2012. Two individuals renested after their initial nesting attempt had apparently failed. The proportion of nests that survived the 30-day incubation period ranged between 0.25 and 1.00 across the 6-yr period, but the number of nests available to monitor annually was typically small (range: $1-15$; Table 2). Across years, $44 \%$ of nests (15 of 34 ) survived the incubation stage. Of the nests that hatched, 87\% (13 of 15) survived to fledge a chick successfully; thus, overall, 38\% (13 of 34 nests) survived both stages and fledged young successfully. The constant daily survival probability was 0.979 (0.005); if extrapolated to a 55-day period from nest initiation to fledging, the nest survival rate was 0.307 (0.083).

During 2011 and 2012, we located 13 nests of 11 radiotagged Marbled Murrelets (2 birds renested). The majority of these nests survived the incubation stage (2011: 0.57; 2012: 0.83) and completed the fledging stage (both years: 1.00; Table 2). Combining both years, the proportion of nests that survived incubation was $0.69(n=13)$ and the proportion that survived chick rearing was $1.00(n=9)$. The overall proportion of Marbled Murrelets that survived both stages and fledged young successfully (69\%; 9 of 13 nests) did not differ from that of Kittlitz's Murrelet in the same years $\left(39 \%\right.$; 9 of 23 nests; $\chi_{1}^{2}=1.926, P=0.17$ ).

\section{Fecundity}

Estimates of the fecundity of Kittlitz's Murrelets ranged from 0.00 (2010) to 0.10 (2011), averaging $0.04 \pm 0.03$ across all years (Figure 4). This mean estimate equates to 4 females successfully fledged for every 100 radio-tagged females in Icy Bay. By comparison, fecundity of Marbled 
TABLE 2. Annual proportions of nests, by species, that successfully completed 2 stages of reproduction at Icy Bay, Alaska, USA, 2007-2012. "Incubation" refers to the period from egg laying to hatching, and "chick-rearing" refers to the period from hatching to fledging ( $n=$ sample size).

\begin{tabular}{|c|c|c|c|c|c|c|c|c|}
\hline \multirow[b]{3}{*}{ Year } & \multicolumn{4}{|c|}{ Kittlitz's Murrelet } & \multicolumn{4}{|c|}{ Marbled Murrelet } \\
\hline & \multicolumn{2}{|r|}{ Incubation } & \multicolumn{2}{|r|}{ Chick-rearing } & \multicolumn{2}{|r|}{ Incubation } & \multicolumn{2}{|r|}{ Chick-rearing } \\
\hline & $n$ & Proportion successful & $n$ & Proportion successful & $n$ & Proportion successful & $n$ & Proportion successful \\
\hline 2007 & 4 & 0.50 & 2 & 1.00 & & & & \\
\hline 2008 & 1 & 1.00 & 1 & 1.00 & & & & \\
\hline 2009 & 2 & 0.50 & 1 & 1.00 & & & & \\
\hline 2010 & 4 & 0.25 & 1 & 0.00 & & & & \\
\hline 2011 & 15 & 0.47 & 7 & 1.00 & 7 & 0.57 & 4 & 1.00 \\
\hline 2012 & 8 & 0.38 & 3 & 0.67 & 6 & 0.83 & 5 & 1.00 \\
\hline All & 34 & 0.44 & 15 & 0.87 & 13 & 0.69 & 9 & 1.00 \\
\hline
\end{tabular}

Murrelets was $0.29(0.05)$ in 2011 and $0.26(0.14)$ in 2012, averaging $0.27(0.11)$ across both years (Figure 4). There was little variation in fecundity between years because most radio-tagged Marbled Murrelets $(n=13$ of 14$)$ nested during our study (Tables 1 and 2). Fecundity of Marbled Murrelets was more than $2 \times$ greater than that of Kittlitz's Murrelets in 2011 and 2012 (Figure 4).

\section{DISCUSSION}

We present the first complete assessment of reproductive performance of Kittlitz's Murrelet and the only direct estimates of reproduction in a glaciated landscape. Our results indicate that the reproductive performance of this species in Icy Bay, although variable, is poor in most years. The low fecundity estimates and unexpectedly low breeding-season survival ( 0.89 for a 60 -day period; Kissling et al. 2015) are consistent with an observed decline (10\% $\mathrm{yr}^{-1}$ ) of this species in Icy Bay between 2002 and 2012 (USFWS 2013, M. Kissling personal observation). We

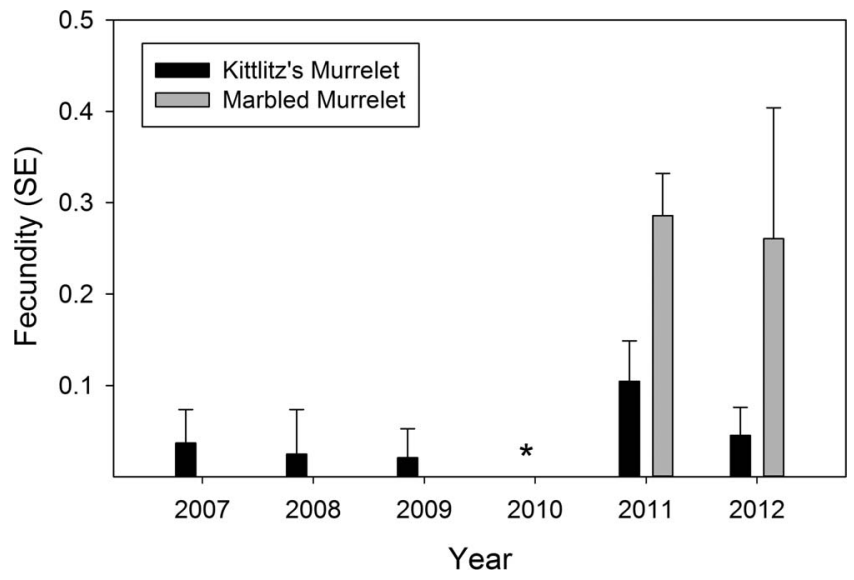

FIGURE 4. Fecundity estimates of Kittlitz's and Marbled murrelets at Icy Bay, Alaska, USA, 2007-2012 (Marbled Murrelet for 2011 and 2012 only). Asterisk indicates that data were available but fecundity was estimated to be zero. highlight 3 key findings regarding reproductive performance of Kittlitz's Murrelets in Icy Bay.

Foremost, during most years of our study, breeding propensity (i.e. the proportion of breeders in the population) was markedly low, averaging 0.20 in a given year. This value is much lower than that reported for Marbled Murrelets in British Columbia (0.65; Bradley et al. 2004), Alaska (0.46-0.50; Barbaree et al. 2014), and California (0.31-0.33; Peery et al. 2004a, Hébert and Golightly 2006); only 1 Marbled Murrelet study, in Washington, found a lower proportion of breeders $(0.13$; T. D. Bloxton, Jr., and M. G. Raphael personal communication). Because our study was the first to measure the breeding propensity of Kittlitz's Murrelet, these similar studies of the congeneric Marbled Murrelet provide the only valid comparisons to put our results into context. In 2011 and 2012, the proportions of radio-tagged Kittlitz's Murrelets nesting increased considerably and were more comparable to those estimates for Marbled Murrelets in similar studies, yet still lower than breeding propensity of Marbled Murrelets in Icy Bay during the same 2-yr period (Table 2).

As with similar studies of radio-tagged Marbled Murrelets (Bradley et al. 2004, Barbaree et al. 2014), we found that male Kittlitz's Murrelets were more likely than females to be breeders. We agree with others that some females may be more affected by capture and radio-tagging activities than males because of the added physiological and energetic burden of developing, carrying, and laying an egg. However, an alternative explanation may be related to the timing of sex-based nesting responsibilities. With the exception of egg laying, male and female share sex-specific nesting responsibilities equally. After the female lays the egg, the male takes the first incubation shift (M. Kissling personal observation), resulting in an increased probability of detecting a male at the nest, especially at those nests that fail early during the incubation stage, as was the case in our study. In future studies aimed at estimating breeding propensity, we suggest radio-tagging only males to avoid 
possible sex bias or radio-tagging birds prior to egg development, perhaps even during the previous breeding season. Although the technology to track murrelets across years exists (e.g., solar-powered satellite transmitters), we have not yet developed an attachment technique that results in sufficient retention of the transmitter through the prebasic molt (M. Kissling personal observation).

Despite a low propensity for nesting, most Kittlitz's Murrelets were in apparent breeding condition in the spring, as evidenced by the presence of a brood patch or elevated VTG. We categorized these individuals as "potential breeders," but we recognize that using brood patch scores and VTG as measures of breeding condition has limitations. The presence of a brood patch only signifies that some of the hormonal changes associated with breeding have occurred and does not necessarily indicate that a murrelet has initiated egg development or incubation (McFarlane Tranquilla et al. 2003a). In Marbled Murrelets, McFarlane Tranquilla et al. (2003a) found that brood patch development can occur quickly or can take weeks to complete. Similarly, elevated VTG levels in female murrelets only indicate that a bird is producing an egg, not necessarily that an egg is laid (McFarlane Tranquilla et al. 2003b). Although both of these methods may indicate reproductive maturity and perhaps even intention to breed, neither is a reliable indicator of actual egg laying or nest initiation (McFarlane Tranquilla et al. 2003a). Therefore, it is likely that we overestimated the number of potential breeders in our sample.

Our second key finding was that nesting success of Kittlitz's Murrelets in Icy Bay was moderate, albeit highly variable (mean $=45 \%$; range: $0-100 \%$ ). Our inferred estimates were higher than those directly measured on Kodiak Island (0.29; Lawonn 2012, R. Corcoran personal communication), on Agattu Island (0.16; Kaler et al. 2009, R. Kaler personal communication), and in the Kakagrak Hills (0.00; M. L. Kissling and S. B. Lewis personal observation), but comparable to those from Adak Island (0.50; R. Kaler personal communication). Similarly, the overall 55-day survival rate (extrapolated from constant daily nest survival probability) was higher in Icy Bay (0.307) than on Kodiak (0.094; Lawonn 2012) or Agattu (0.060; Kaler et al. 2009). Although these large differences in mean estimates of nesting success are notable and may be biologically meaningful, we caution against drawing broad inferences, because comparisons among sites should control for year, as our data suggest considerable variation among years for a given site. Also, methods for locating and monitoring nests varied among sites. Development of standard protocols for locating and monitoring active nests on foot would allow for testing of hypotheses about source-sink patch dynamics, perhaps elucidating possible reasons for the apparent large variation in reproductive output among study sites.
Finally, Kittlitz's Murrelet nests in Icy Bay were more likely to fail during incubation than during chick rearing. This result is consistent with results from Adak Island ( $R$. Kaler personal communication) and the Kakagrak Hills (M. L. Kissling and S. B. Lewis personal observation), but different from the 2 larger studies on Agattu and Kodiak islands. On Agattu, nest survival probability was similar between incubation (0.26) and chick rearing (0.22; Kaler et al. 2009); and on Kodiak, Lawonn (2012) reported an abrupt decline in daily nest survival rate at hatching. The same caution applies here as stated above, yet we note the similarities between nesting success and stage of failure at Adak Island and Icy Bay even though we are unable to draw inferences from them.

Together, our data demonstrate that Kittlitz's Murrelets were outperformed by Marbled Murrelets in all facets of reproduction in Icy Bay, resulting in fecundity estimates more than doubled for the latter species (Figure 4). Further supporting this finding, we captured only 5 hatch-year Kittlitz's Murrelets during 68 capture nights in late July and early August over a 4-yr period (2008-2011). Although not directly comparable because of varying degrees of effort between species, we captured 25 hatchyear Marbled Murrelets across the same time frame even though the abundance of Kittlitz's Murrelets was nearly $10 \times$ that of Marbled Murrelets during the breeding season (Kissling et al. 2011).

As with all field studies, the validity of our results hinges on how well we met the necessary assumptions of our methods and analysis. We identified 3 possible sources of bias that may have contributed to the small annual proportions of Kittlitz's Murrelets that nested in our study (also described in Bradley et al. 2004, Peery et al. 2004b) and 1 potential source that may have contributed to the high estimates of nesting success.

First, it is possible that a few prebreeders were included in our sample because we could not distinguish individuals that reached breeding age from those that did not. However, we believe that the number of prebreeders in our sample must have been small, because 2-yr-old Kittlitz's Murrelets represented the only nondistinguishable age class that would qualify as prebreeders, given the presumed age of first breeding (third year) and long life span of Brachyramphus (approximately 10-15 yr; Piatt et al. 2007, USFWS 2013). In addition, during the 6 yr of our study, only 1 of 920 individuals captured was SY, further supporting the assumption that the number of prebreeders in our sample was probably very low.

Second, capture or radio-tagging activities may have interrupted or negatively affected the breeding effort of Kittlitz's Murrelets. The effects of capture and radio-tagging of murrelets are not clear and are hard to assess, given the difficulty of finding their nests in the absence of radiotelemetry (Figure 2B). Several studies have demonstrated a 
possible negative effect of radio-tagging on the breeding propensity of Marbled Murrelets (McFarlane Tranquilla 2001, Peery et al. 2004a, Barbaree et al. 2014), but not necessarily on their breeding success or timing (McFarlane Tranquilla 2001, McFarlane Tranquilla et al. 2003a, Bradley et al. 2004). Another study attributed negative impacts to the use of anesthesia, not radio-tagging (Hébert and Golightly 2006). In other alcids, some studies found that individuals equipped with radio-transmitters experienced lower reproductive success (Croll et al. 1996, Ackerman et al. 2004, Whidden et al. 2007), but other studies did not report any measurable adverse effects (Ballard et al. 2001, Hamel et al. 2004, Newman et al. 2005; for a summary, see Barron et al. 2010). We cannot rule out the possibility that our estimates of the breeding propensity of Kittlitz's Murrelets were biased low compared to the population at large because of capturing and radio-tagging activities. However, we emphasize that we used the same methods to study Kittlitz's and Marbled murrelets, and all measures of reproduction were much higher for the latter. Although the Marbled Murrelet may somehow be able to tolerate the stress of capture and radio-tagging better than the similarly sized Kittlitz's Murrelet, we cannot conceive of a reason that these activities would grossly bias our results for the breeding propensity of Kittlitz's Murrelet and not those for Marbled Murrelets. Regardless, we consider our estimates of breeding propensity for both species to be minimum values.

The third, and perhaps most reasonable, mechanism by which our methods may have produced estimates of breeding propensity that were biased low was due to missing early failures of nesting attempts. We were not able to locate radio-tagged birds daily because of weather and logistical constraints; instead, we located birds $2-5$ times $\mathrm{wk}^{-1}$ for $\geq 8 \mathrm{wk}$ following capture and radio-tagging. Thus, 2 situations may have occurred: A nest failed between telemetry flights (i.e. no possible way to detect it) or a nest failed before it was located (i.e. a nest detection issue). Bradley et al. (2004) found that it took $\sim 75 \%$ of the 30-day incubation period of a Marbled Murrelet in order to reach a 95\% probability of detecting its nest, given that a nest was available to be detected. Generally, daily detection probabilities in our study were high for birds on the water $(>0.97)$ but low for the initial detection of nests (0.30; Kissling et al. 2015), largely because of the mountainous terrain and inclement weather commonly encountered in Icy Bay. However, there were few radio-tagged individuals that demonstrated an intermittent pattern on the water and for which, ultimately, a nest was not located when the weather permitted safe flight into the mountains. Further, it is worth noting that an underestimation in breeding propensity also would have resulted in an overestimation of nesting success, and therefore fecundity would not change.

Last, because we were unable to monitor most nests directly, we had to infer nesting success by assuming a nest to be successful if the radio-tagged bird visited the nest for $\geq 18$ days after hatching. This assumption may have underestimated the time required to fledge a chick, perhaps biasing our value of nesting success high. The majority of nest failures recorded in our study occurred during the incubation stage, not during the chick-rearing stage (Table 2) when it was more difficult to document activity of the radio-tagged bird at the nest (as opposed to incubation, when the adult remains at the nest for 24-72 hr visit ${ }^{-1}$; M. Kissling personal observation). Regardless, among the 22 successful nests (13 Kittlitz's and 9 Marbled), only 2 were active for the minimum 18-day chick-rearing period (1 of each species); the remainder of nests (91\%) were visited regularly by the radio-tagged parent for $\geq 20$ days after hatching. Nonetheless, our estimates of nesting success should be considered maximum values.

Assessing the reproductive performance of a dispersednesting seabird like Kittlitz's Murrelet is inherently difficult, particularly in glacial landscapes, and it is unlikely that technological advances in the near future will enable more efficient or accurate methods of inference. Yet the low reproductive output of Kittlitz's Murrelet reported here raises concern. Thus, we offer the following recommendations for future study of the reproductive performance of this species.

First, we emphasize the need for longer-term studies to better understand factors driving the variation in the breeding propensity and fecundity of this species. Our study of 6 yr constitutes roughly one-third to half of the life span of an individual Kittlitz's Murrelet (Day et al. 1999), not nearly enough time to evaluate whether the observed reproductive performance at the population level was "normal" or not. Second, we urge future study of Kittlitz's Murrelets to include the prebreeding and early breeding periods, an understudied portion of its annual cycle. Even if our estimates of breeding propensity were biased low because of early failure of nests prior to detection, those failures occurred early during incubation, a period that imposes great demands on parents, as Brooke (1990) proposed for Manx Shearwaters (Puffinus puffinus). Lastly, we encourage researchers to conduct hypothesisbased studies of Kittlitz's Murrelets in present-day glacially influenced and non-glacially influenced areas and in comparison to the Marbled Murrelet, where possible, using similar methods. This approach will help us determine the factors that limit or drive the reproductive performance of Kittlitz's Murrelets and their ability to adapt to changes in their marine and terrestrial habitats.

\section{ACKNOWLEDGMENTS}

We thank the $100+$ volunteers and colleagues who provided advice, lent equipment, or assisted with capturing, tracking, and surveying murrelets in Icy Bay. We are especially grateful 
to N. Hatch, L. Kenney, J. Felis, S. Schoen, N. Hajdukovich, and A. Schaefer for their hard work in the field, often under trying conditions. We thank T. Williams, Simon Fraser University, for laboratory analyses and assisting with interpretation of the VTG results. We also thank Icy Bay Lodge, Alsek Air, Temsco Helicopters, Coastal Helicopters, and several individuals and businesses in Yakutat for many years of support. We particularly acknowledge L. Hartley for safely flying $>800 \mathrm{hr}$ of telemetry flights. We thank Wrangell-St. Elias National Park, Chugach Native Corporation, and Alaska Mental Health Trust Authority for permitting access to their lands. We are grateful to two anonymous reviewers for suggestions that improved the manuscript.

Funding statement: Funding for this study was provided primarily by the National Park Service and U.S. Fish and Wildlife Service (USFWS).

Ethics statement: All capture and handling procedures were reviewed and approved by the Alaska Department of Fish and Game (2007-2009) and USFWS (2010-2012) Institutional Animal Care and Use Committee. The findings and conclusions in this manuscript are the authors' and do not necessarily represent the views of USFWS.

\section{LITERATURE CITED}

Ackerman, J. T., J. Adams, J. Y. Takekawa, H. R. Carter, D. L. Whitworth, S. H. Newman, R. T. Golightly, and D. L. Orthmeyer (2004). Effects of radiotransmitters on the reproductive performance of Cassin's Auklets. Wildlife Society Bulletin 32: 1229-1241.

Ballard, G., D. G. Ainley, C. A. Ribic, and K. R. Barton (2001). Effect of instrument attachment and other factors on foraging trip duration and nesting success of Adélie Penguins. The Condor 103:481-490.

Barbaree, B. A., S. K. Nelson, B. D. Dugger, D. D. Roby, H. R. Carter, D. L. Whitworth, and S. H. Newman (2014). Nesting ecology of Marbled Murrelets at a remote mainland fjord in southeast Alaska. The Condor: Ornithological Applications 116:173-184.

Barclay, D. J., J. L. Barclay, P. E. Calkin, and G. C. Wiles (2006). A revised and extended Holocene glacial history of Icy Bay, Southern Alaska, U.S.A. Arctic, Antarctic, and Alpine Research 38:153-162.

Barron, D. G., J. D. Brawn, and P. J. Weatherhead (2010). Metaanalysis of transmitter effects on avian behaviour and ecology. Methods in Ecology and Evolution 1:180-187.

Bond, J. C., D. Esler, and T. D. Williams (2008). Breeding propensity of female Harlequin Ducks. Journal of Wildlife Management 72:1388-1393.

Bradley, R. W., F. Cooke, L. W. Lougheed, and W. S. Boyd (2004). Inferring breeding success through radio-telemetry in the Marbled Murrelet. Journal of Wildlife Management 68:318331.

Brooke, M. (1990). The Manx Shearwater. Poyser, London, UK.

Cam, E., J. E. Hines, J. Y. Monnat, J. D. Nichols, and E. Danchin (1998). Are adult nonbreeders prudent parents? The Kittiwake model. Ecology 79:2917-2930.

Croll, D. A., J. K. Jansen, M. E. Goebel, P. L. Boveng, and J. L. Bengtson (1996). Foraging behavior and reproductive success in Chinstrap Penguins: The effects of transmitter attachment. Journal of Field Ornithology 67:1-9.
Day, R. H. (1996). Nesting phenology of Kittlitz's Murrelet. The Condor 98:433-437.

Day, R. H. (2011). Evaluating population trends of Kittlitz's Murrelets in Alaska. Final Report to Alaska Department of Fish and Game, Juneau, Alaska. ABR-Environmental Research and Services, Fairbanks, AK, USA. http://www.adfg.alaska.gov/ static/species/specialstatus/pdfs/kittlitzmurrelet_2011_ population_trends.pdf

Day, R. H., K. J. Kuletz, and D. A. Nigro (1999). Kittlitz's Murrelet (Brachyramphus brevirostris). In The Birds of North America 435 (A. Poole and F. Gill, Editors). Academy of Natural Sciences, Philadelphia, PA, and American Ornithologists' Union, Washington DC, USA. doi:10.2173/bna.435

Day, R. H., and D. A. Nigro (2004). Is the Kittlitz's Murrelet exhibiting reproductive problems in Prince William Sound, Alaska? Waterbirds 27:89-95.

Dinsmore, S. J., G. C. White, and F. L. Knopf (2002). Advanced techniques for modeling avian nest survival. Ecology 83: 3476-3488.

Hamel, N. J., J. K. Parrish, and L. L. Conquest (2004). Effects of tagging on behavior, provisioning, and reproduction in the Common Murre (Uria aalge), a diving seabird. The Auk 121: 1161-1171.

Hébert, P. N., and R. T. Golightly (2006). Movements, nesting, and response to anthropogenic disturbance of Marbled Murrelets (Brachyramphus marmoratus) in Redwood National and State Parks, California. Final Report. California Department of Fish and Game Report 2006-02. http://www.dot.ca.gov/newtech/ researchreports/2002-2006/2006/fhwa-ca-ir-2006-04.pdf

Hodges, J. I., and M. D. Kirchhoff (2012). Kittlitz's Murrelet Brachyramphus brevirostris population trend in Prince William Sound, Alaska: Implications of species misidentification. Marine Ornithology 40:117-120.

Janssen, M. H., P. Arcese, T. K. Kyser, D. F. Bertram, L. McFarlane Tranquilla, T. D. Williams, and D. R. Norris (2009). Pre-breeding diet, condition and timing of breeding in a threatened seabird, the Marbled Murrelet Brachyramphus marmoratus. Marine Ornithology 37:33-40.

Kaler, R. S. A., L. A. Kenney, and B. K. Sandercock (2009). Breeding ecology of Kittlitz's Murrelets at Agattu Island, Aleutian Archipelago, Alaska. Waterbirds 32:363-373.

Kirchhoff, M. D., J. R. Lindell, and J. I. Hodges (2014). From critically endangered to least concern?-A revised population trend for the Kittlitz's Murrelet in Glacier Bay, Alaska. The Condor: Ornithological Applications 116:24-34.

Kissling, M. L., P. M. Lukacs, S. M. Gende, and S. B. Lewis (2015). Multi-state mark-recapture model to estimate survival of a dispersed-nesting seabird, the Kittlitz's Murrelet. Journal of Wildlife Management 79:20-30.

Kissling, M. L., P. M. Lukacs, S. B. Lewis, S. M. Gende, K. J. Kuletz, N. R. Hatch, S. K. Schoen, and S. Oehlers (2011). Distribution and abundance of the Kittlitz's Murrelet Brachyramphus brevirostris in selected areas of southeastern Alaska. Marine Ornithology 39:3-11.

Kuletz, K. J., C. S. Nations, B. Manly, A. Allyn, D. B. Irons, and A. McKnight (2011a). Distribution, abundance and population trends of the Kittlitz's Murrelet Brachyramphus brevirostris in Prince William Sound, Alaska. Marine Ornithology 39:97-109. Kuletz, K. J., C. S. Nations, B. Manly, A. Allyn, D. B. Irons, and A. McKnight (2013). Brachyramphus murrelet trends and the 
Prince William Sound, Alaska surveys: A response to Hodges and Kirchhoff. Marine Ornithology 41:69-71.

Kuletz, K. J., S. G. Speckman, J. F. Piatt, and E. A. Labunski (2011b). Distribution, population status and trends of Kittlitz's Murrelet Brachyramphus brevirostris in Lower Cook Inlet and Kachemak Bay, Alaska. Marine Ornithology 39:85-95.

Kuletz, K. J., S. W. Stephensen, D. B. Irons, E. A. Labunski, and K. M. Brenneman (2003). Changes in distribution and abundance of Kittlitz's Murrelets Brachyramphus brevirostris relative to glacial recession in Prince William Sound, Alaska. Marine Ornithology 31:133-140.

Lawonn, M. J. (2012). Breeding ecology and nest site selection of Kittlitz's Murrelets on Kodiak Island, Alaska. M.S. thesis, Oregon State University, Corvallis, OR, USA.

Lougheed, C., L. W. Lougheed, F. Cooke, and S. Boyd (2002). Local survival of adult and juvenile Marbled Murrelets and their importance for estimating reproductive success. The Condor 104:309-318.

McFarlane Tranquilla, L. (2001). Using multiple methods to describe breeding, stress response, and disturbance of Marbled Murrelets, Brachyramphus marmoratus. M.Sc. thesis, Simon Fraser University, Burnaby, British Columbia, Canada.

McFarlane Tranquilla, L., R. W. Bradley, D. B. Lank, T. D. Williams, L. W. Lougheed, and F. Cooke (2003a). The reliability of brood patches in assessing reproductive status in the Marbled Murrelet: Words of caution. Waterbirds 26:108-118.

McFarlane Tranquilla, L., T. Williams, and F. Cooke (2003b). Using vitellogenin to identify interannual variation in breeding chronology of Marbled Murrelets (Brachyramphus marmoratus). The Auk 120:512-521.

Mills, L. S. (2012). Conservation of Wildlife Populations: Demography, Genetics, and Management. Wiley, West Sussex, UK.

Newman, S. H., H. R. Carter, D. L. Whitworth, and J. G. Zinkl (2005). Health assessments and stress response of Xantus's Murrelets to capture, handling, and radio-marking. Marine Ornithology 33:147-154.

Newman, S. H., J. Y. Takekawa, D. L. Whitworth, and E. Burkett (1999). Subcutaneous anchor attachment increases retention of radio transmitters on seabirds: Xantus' and Marbled murrelets. Journal of Field Ornithology 70:520-534.
Peery, M. Z., S. R. Beissinger, S. H. Newman, B. H. Becker, E. Burkett, and T. D. Williams (2004a). Individual and temporal variation in inland flight behavior of Marbled Murrelets: Implications for population monitoring. The Condor 106:344353.

Peery, M. Z., S. R. Beissinger, S. H. Newman, E. B. Burkett, and T. D. Williams (2004b). Applying the declining population paradigm: Diagnosing causes of poor reproduction in the Marbled Murrelet. Conservation Biology 18:1088-1098.

Piatt, J. F., M. Arimitsu, G. Drew, E. N. Madison, J. Bodkin, and M. D. Romano (2011). Status and trend of the Kittlitz's Murrelet Brachyramphus brevirostris in Glacier Bay, Alaska. Marine Ornithology 39:65-75.

Piatt, J. F., K. J. Kuletz, A. E. Burger, S. A. Hatch, V. L. Friesen, T. P. Birt, M. L. Arimitsu, G. S. Drew, A. M. A. Harding, and K. S. Bixler (2007). Status review of the Marbled Murrelet (Brachyramphus marmoratus) in Alaska and British Columbia. U.S. Geological Survey Open-File Report 2006-1387.

Pyle, P. (2008). Identification Guide to North American Birds, part 2: Anatidae to Alcidae. Slate Creek Press, Point Reyes Station, CA, USA.

Schaub, M., and F. Abadi (2011). Integrated population models: A novel analysis framework for deeper insights into population dynamics. Journal of Ornithology 152 (Supplement 1):S227-S237.

Sealy, S. G. (1974). Breeding phenology and clutch size in the Marbled Murrelet. The Auk 91:10-23.

U.S. Fish and Wildlife Service (2013). 12-month finding on a petition to list Kittlitz's Murrelet as an endangered or threatened species. Federal Register 78:61764.

Vanderkist, B. A., T. D. Williams, D. F. Bertram, L. W. Lougheed, and J. L. Ryder (2000). Indirect, physiological assessment of reproductive state and breeding chronology in free-living birds: An example in the Marbled Murrelet (Brachyramphus marmoratus). Functional Ecology 14:758-765.

Whidden, S. E., C. T. Williams, A. R. Breton, and C. L. Buck (2007). Effects of transmitters on the reproductive success of Tufted Puffins. Journal of Field Ornithology 78:206-212.

Whitworth, D. L., J. Y. Takekawa, H. R. Carter, and W. R. Mclver (1997). A night-lighting technique for at-sea capture of Xantus' Murrelets. Colonial Waterbirds 20:525-531. 